\title{
PENDIDIKAN KEWIRAUSAHAAN MELALUI PENGEMBANGAN EKONOMI KREATIF SABLON CUKIL
}

\author{
Aden Wijdan SZ \\ Universitas Islam Indonesia, Yogyakarta \\ aden.wijdan@gmail.com \\ Junanah \\ Universitas Islam Indonesia, Yogyakarta \\ junanah@uii.ac.id \\ DOI: 10.20885/tarbawi.vol14.iss1.art5
}

\begin{abstract}
The background of the service is that the development of the Kawruh Lumbung Studio is needed so that it can be further developed through the Cukil Screen Printing Business. The Cukil screen printing business is considered to be important expertise to accommodate creativity and improve the community's economy, especially young people to not migrate but focus on working to support the progress of Petir Village. The lumbung kawruh studio has several routine activities, including learning to read and write Javanese script, learning to dance and a mini library. The various creative potentials above, on the other hand, can be used as a medium for entrepreneurship education for youth in the area. The purpose of this service is to develop the art of Cukil (Cukil screen printing) which is applied to tshirts and bags, and to make it a medium for entrepreneurship education for youth in the area. The results of this service process include young people who have had cut-out screen printing skills through the entrepreneurship education process using the focus group discussion method, workshops and the practice of screen printing.
\end{abstract}




\title{
$e^{I-T a r b a w j ~ A d e n ~ W i j d a n ~ S Z ~ \& ~ J u n a n a h ~}$
}

Keywords: Entrepreneurship education, development, Cukil screen printing.

\begin{abstract}
Abstrak
Latar belakang pengabdian adalah diperlukan pengembangan dari Sanggar Lumbung Kawruh agar dapat lebih berkembangnya melalui usaha Sablon Cukil. Usaha sablon cukil dinilai dapat menjadi andalan untuk menampung kreatifitas dan peningkatan ekonomi masyarakat khususnya kaum muda agar tidak mudah untuk merantau namun bisa fokus untuk berkarya untuk mendukung kemajuan Desa Petir. Sanggar lumbung kawruh mempunyai beberapa kegiatan rutin antara lain belajar membaca dan menulis tulisan jawa, belajar menari dan perpustakaan mini. Beragam potensi kreatifitas di atas, di sisi lain dapat dijadikan sebagai media pendidikan kewirausahaan bagi pada pemuda di daerah tersebut. Tujuan pengabdian ini untuk mengembangkan seni cukil (sablon cukil) yang diaplikasikan kaos dan tas, serta menjadikannya sebagai media pendidikan kewirausahaan bagi para pemuda di daerah tersebut. Hasil dari proses pengabdian ini di antaranya para pemuda telah mempunyai keterampilan sablon cukil melalui proses pendidikan kewirausahaan dengan metode focus grup discussion, workshop dan praktek sablon cukil.
\end{abstract}

Kata Kunci: Pendidikan Kewirausahaan, Pengembangan, Sablon Cukil. 


\section{Pendahuluan}

Seni adalah karya yang dalam penciptaannya melibarkan ide, gagasan, gerak hati, perasaan, pikiran, membuat, menyusun, memproses sampai membuahkan sebuah wujud yang secara visual punyai nilai keindahan dan menimbulkan perasaan/ subyektif (John Felix, 2021). Sedangkan kreatifitas adalah hasil aktivitas yang bersifat baru, berguna dan dapat dimengerti oleh orang (Diana Vidya Fakhriyani, 2016). Kreatif adalah jika berasal dari pemikiran yang asli/ orisinil, rasa ingin tahu, kerja keras, lincah dan fleksibel/ bebas dalam berpikir serta memiliki kemandirian dimana karya yang dihasilkan merupakan penemuan dari pendekatan atau terobosan baru. Sablon cukil saat ini masih di lestarikan oleh Sanggar Lumbung Kawruh, sablon cukil merupakan sebuah karya yang dihasilkan dari proses yang mempunyai nilai seni tinggi. Sanggar Lumbung Kawruh sesuai dengan nama nya menjadi Gudang Ilmu Pengetahuan bagi remaja dan anak - anak Padukuhan Ngurak Urak khususnya dan Kalurahan Petir pada umumnya. Kegiatan Sanggar Lumbung Kawruh antara lain belajar bersama, belajar wayang, melukis, membatik hingga membaca dan meminjam buku di perpustakaan yang ada di Sanggar Lumbung Kawruh. Hampir semua kegiatan di Sanggar Lumbung Kawruh tidak lepas dari Dunia Pendidikan.

Pendidikan tidak bisa dilepaskan dari masyarakat, karenanya proses pendidikan perlu memperhatikan keberadaan dan perkembangan masyarakat serta lembaga lain 


\section{$e^{I-T a r b a w j ~ A d e n ~ W i j d a n ~ S Z ~ \& ~ J u n a n a h ~}$}

baik itu langsung maupun tidak berpengaruh terhadap kelangsungan pendidikan. Kemajuan bangsa tidak bisa di lepaskan dari maju dan mundur nya pendidikan, karena melalui pendidikan generasi penerus bangsa ini dipersiapkan untuk meneruskan kehidupan bangsa agar lebih maju lagi. Sistem pendidikan yang baik akan menghasilkan sumber daya manusia yang siap bersaing menhadapi kemajuan zaman di era globalisasi seperti ini. Pendidikan merupakan investasi dimana pembangunan ekonomi, oleh sebab itu, bagaimanapun juga pembangunan ekonomi membutuhkan kualitas Sumber Daya Manusia yang unggul baik dalam kapasitas penguasaan Ilmu Pengetahuan dan Teknologi maupun sikap mental, sehingga dapat menjadi subjek atau pelaku pembangunan yang handal (Agus Arijanto, 2012).

Salah satu pendidikan yang harus senantiasa dikembangkan adalah pendidikan berwawasan kewirasusahaan. Pendidikan yang berwawasan kewirausahaan ditandai dengan proses pendidikan yang menerapkan prinsip-prinsip dan metodologi ke arah pembentukan kecakapan hidup (life skill) (Endang Mulyani, 2011). Tujuan Pendidikan kewirausahaan adalah terampil memanfaatkan peluang dalam mengembangkan usahanya dengan tujuan untuk meningkatkan kehidupannya (Endang Mulyani, 2011). Hal tersebut di atas relevan dengan proses berwirausaha yang menekankan pada proses penerapan kreativitas dan inovasi dalam memecahkan persoalan dan menemukan peluang untuk memperbaiki kehidupan (Kasmir, 2012). 
Latar Belakang Kegiatan pengabdian masyarakat di Kalurahan Petir khususnya pada Sanggar Lumbung Kawruh ini untuk mendorong berkembangnya seni sablon cukil sebagai upaya untuk mengembangkan kreatifitas bagi generasi muda Kalurahan Petir sebagai bagian dari pelestrian seni cukil di Gunungkidul. Seni sablon cukil satu - satunya yang ada di Gunungkidul yang masih exsis seiring bergantinya zaman yang serba canggih seperti saat ini, Sanggar. Lumbung Kawruh masih selalu menjaga dan melestarikan seni tersebut tidak hanya sebatas mempertahankan tetapi juga memperkenalkan lagi ke kalangan anak - anak milenial agar mengenal apa itu seni sablon cukil (https://www.wartahandayani.com/). Mayoritas masyarakat Kalurahan Petir mempunyai mata pencaharian sebagai petani maupun buruh tani ini masih sangat menjaga adat, tradisi dan budaya yang ada, sehingga Kalurahan Petir di tetapkan sebagai Rintisan Kalurahan Budaya melalui SK Bupati Gunungkidul tahun 2017. Sejak ditetapkan sebagai Rintisan Kalurahan Budaya tahun 2017, dalam tiga tahun berturut - turut yaitu tahun 2018, tahun 2019 dan tahun 2020 Kalurahan Petir keluar sebagai Juara 1 Gelar Potensi Rintisan Kalurahan Budaya se Gunungkidul. Setiap Gelar Potensi Rintisan Kalurahan Budaya Gunungkidul Sablon Cukil menjadi salah satu andalan bagi Kalurahan Petir

Desa Petir adalah sebuah desa dengan mayoritas masyarakat sebagai Petani namun mempunyai kekayaan Budaya dan Kesenian yang mengakar kuat, hal ini sejalan 


\section{$\mathrm{e}^{\mathrm{I}-\text { Tarbawj Aden Wijdan SZ \& Junanah }}$}

dengan ditetapkan nya petir sebagai Desa Rintisan Budaya melalui SK Bupati Gunungkidul tahun 2017. Salah satu yang menjadi andalan ekonomi kreatif di Desa Petir adalah Sablon Cukil yang selalu menyertai Desa Petir saat tampil alam Gelar Potensi Desa Rintisan Budaya di Gunungkidul, hal inilah yang menjadi latar belakang kegiatan pengabdian di Desa Petir khususnya pada Sanggar Lumbung Kawruh agar Sablon Cukil dapat menjadi andalan untuk menampung kreatifitas dan peningkatan ekonomi masyarakat khusus nya kaum muda agar tidak mudah untuk merantau namun bisa fokus untuk berkarya untuk mendukung kemajuan dan perkembangan Desa Petir.

Permasalahan klasik yang di hadapi oleh Sanggar Lumbung Kawruh dalam mengembangkan Sablon Cukil adalah dari Keterbatasan Sumber Daya Manusia yang ada, baik Sumber Daya Kreatif maupun dari sisi Pemasaran Produk nya. Dewasa ini pasar industri kaos di dominasi oleh kaos sablon konvensional pabrikan yang dari sisi harga masih lebih rendah dibandingkan hasil dari Kaos Sablon Cukil. Toko Kaos dan Distro di dominasi oleh hasil kaos dengan desain komputer dan di cetak secara manual melalui Screen. Kaos dengan Sablon cukil sebenarnya memiliki keunggulan untuk bersaing, karena melalui proses yang unik serta lebih mengedepankan Seni dari segi desain yang di hasilkanpun sangat kuat sekali pesan pesan moral yang di sampaikan Keunggulan dari kaos sablon cukil tersebut diantaranya: 1) bercita rasa seni yang lebih tinggi 
Pendidikan Kewirausahaan Melalui Pengembangan Ekonomi... el-Tarbawj

di banding kaos sablon pabrikan; 2) desain yang dihasilkan melukiskan kegiatan sosial atau kritik sosial; 3) pesan dalam desain Kaos Sablon Cukil mewakili pada kondisi masyarakat yang ada; 4) karakter dari karya sablon cukil ini mengandung filosofi yang bagus, menarik dan merakyat.

Hambatan yang menyebabkan sablon cukil kurang dapat berkembang seperti yang di harapkan di antaranya adalah 1) sablon yang dihasilkan kebanyakan hanya satu warna; 2) proses produksi nya lebih lama; 3) masyarakat belum menilai sebuah karya dari segi seni tinggi yang dihasilkan. Sehingga pengabdian ini dilakukan dengan tujuan untuk mengembangkan sumber daya yang ada melalui pendidikan kewirausahaan bagi kaum muda di Desa Petir agar bisa berkreasi dan berkarya melalui ketrampilan sablon cukil, serta memaksimalkan dan membuat differensiasi produk sablon cukil untuk pengembangan aktivitas dan kreasi Sanggar Lumbung Kawruh.

\section{Metode Pengabdian}

Sasaran pengabdian ini adalah masyarakat yang tergabung dalam Sanggar Lumbung Kawruh yang berada di Padukuhan Ngurak Urak yang merupakan pusat pengembangan Sablon Cukil di Desa Petir Kecamatan Rongkop Gunungkidul. 


\section{$\mathrm{e}^{\mathrm{I}-\text { Tarbawj Aden Wijdan SZ \& Junanah }}$}

Metode pengabdian yang digunakan adalah workshop pengembangan ekonomi kreatif sablon cukil. Model pemberdayaan masyarakat untuk mengatasi persolan di atas menggunakan metode participatory rural appraisal (PRA). Pertimbangan dipilihnya metode ini adalah bahwa yang menghadapi masalah adalah mitra. Oleh karena itu, keterlibatan mitra dalam penentuan pemecahan masalah yang dihadapi dan penyelesaiannya sangat diperlukan.

Tahapan metode workshop yang telah dilakukan adalah sebagai berikut:

1. Koordinasi

Dalam Koordinasi bersama Kepala Desa Petir ini membahas tentang persiapan tahap tahap pelaksanaan sekaligus melakukan persamaan persepsi untuk pengembangan sablon cukil sebagai salah satu icon unggulan dalam mengembangkan ekonomi kreatif dalam bidang seni.

2. Focus Grup Discussion

Diskusi dilakukan bersama Ketua Sanggar Lumbung Kawruh, Kepala Dukuh Ngurak Urak dan Kepala Desa Petir ini dimaksudkan untuk menjelaskan tahapan pelaksanaan pengabdian masyarakat ini

3. Workshop

Workshop dan Pelatihan ini dimaksudkan untuk mengembangkan Sumber Daya Manusia yang ada di Desa 
Petir khususnya guna menyiapkan lebih banyak generasi muda untuk dapat berkreasi untuk desain sablon cukil

4. Pelatihan Promosi Media Sosial

Hasil karya yang di selesaikan peserta di hari kedua dilanjutkan dengan pelatihan untuk memasarkan karya karya yang dihasilkan di Media Sosial.

5. Pembuatan Media Promosi

a. Foto produk

Hasil kaos sablon cukil dibuat sebagai koleksi foto dengan mengambil di beberapa tempat sebagai bahan promosi di media sosial.

b. Video produksiUntuk mendukung foto produk yang dihasilkan dibuat video mengenai sablon cukil sebagai media yang dapat memperkuat foto produk yang dihasilkan.

\section{Hasil dan Pembahasan}

Usaha Mikro dan Kecil Menengah (UMKM) di Kalurahan Petir berkembang dengan baik di setiap padukuhan ada usaha toko/ warung kelontong, sementara itu usaha makanan lokal juga berkembang di setiap padukuhan seperti Keripik, Emping, Tempe. Rengginan, Lempeng, Ampyang, Krecek dan sebagainya, ada juga usaha mebel dan konveksi baik itu konveksi pakaian maupun konveksi tas. Selain itu Kalurahan Petir juga mempunyai motif batik khas yaitu Batik Gudhe dan 


\section{$\mathrm{e}^{\mathrm{I}-\text { Tarbawj Aden Wijdan SZ \& Junanah }}$}

Batik ketela yang diproduksi oleh kelompok Batik Prita Lestari yang berada di Padukuhan Petir A.

Sanggar yang beralamat di Padukuhan Ngurak Urak ini adalah satu diantara beberapa sanggar yang ada di Kalurahan Petir, Sanggar Lumbung Kawruh tergolong cukup maju dalam kegiatan dan aktivitas nya. Lumbung kawruh yang artinya adalah Gudang Ilmu Pengetahuan sehingga sanggar lumbung kawruh menjadi gudang ilmu Pengetahuan bagi anak - anak dan generasi muda Kalurahan Petir pada umumnya dan khususnya yang ada di Padukuhan Ngurak Urak.

Beberapa kegiatan yang rutin dilaksanakan oleh Sanggar Lumbung Kawruh diantara nya Belajar Bersama, Diskusi Tradisi dan Budaya, Dolanan Anak dan lain sebagainya. Yang menjadi daya tarik anak - anak untuk datang dan bergabung dalam kegiatan Sanggar Lumbung Kawruh adalah adanya Perpustakaan. Walaupun masih relatif belum lengkap namun cukup untuk mengajak anak - anak agar mempunyai kebiasaan membaca. Selama ini Sanggar Lumbung Kawruh masih mengandalkan donatur untuk melaksanakan seluruh kegiatan nya termasuk buku - buku yang ada di perpustakaan merupakan sumbangan dari berbagai pihak. Salah satu yang menjadi konsentrasi untuk keberlangsungan Sanggar Lumbung Kawruh adalah produk sablon cukil, pemasukan dari penjualan sablon cukil memang masih relatif sedikit, selama ini penjualan lebih banyak dilakukan saat Sanggar Lumbung Kawruh mengikuti pameran, sedangkan penjualan melalui media online 
seperti instagram masih belum maksimal. Pemasukan lain yang sering didapat dari seni cukil ini adalah melalui undangan dari berbagai pihak termasuk sekolah - sekolah untuk mengisi acara semacam workshop untuk memberi pelajaran melukis dan mencukil di papan MDF hingga penerapan di media tertentu seperti kaos. Jika melihat dari kegiatan - kegiatan yang dilakukan oleh Sanggar Lumbung Kawruh sangat jelas terlihat bahwa sanggar ini konsen dalam kegiatan yang mengarah kepada pendidikan khususnya pendidikan seni.

Pendidikan Seni budaya dan keterampilan (SBK) adalah salah satu mata pelajaran umum yang berhubungan dengan bakat yang di ajarkan di sekolah. Pendidikan seni budaya dan keterampilan di berikann di sekolah karena keunikan, kebermaknaan dan bermanfaat terhadap kebutuhan perkembangan siswa (Barmin, Eko Wijiono, 2007). Berdasarkan KTSP, ruang lingkup pelajaran seni budaya dan prakarya meliputi aspek-aspek sebagai berikut: a) Seni rupa, mencakup pengetahuan, keterampilan, dan nilai dalam menghasilkan karya seni berupa lukisan, patung, ukiran, cetak mencetak, dan sebagainya, b) Seni musik, mencakup kemampuan untuk menguasai olah vokal, memainkan alat musik, apresiasi karya musik, c) Seni tari, mencakup keterampilan gerak berdasarkan olah tubuh dengan dan tanpa rangsangan bunyi, apresiasi terhadap gerak tari, d) Seni drama, mencakup keterampilan pementasan dengan memadukan seni musik, seni tari dan peran, e) Keterampilan, mencakup segala aspek kecakapan 


\section{$\mathrm{e}^{\mathrm{I}-\text { Tarbawj Aden Wijdan SZ \& Junanah }}$}

hidup (life skills) yang meliputi keterampilan personal, keterampilan sosial, keterampilan vokasional dan keterampilan akademik. Pendidikan seni budaya sebagai mata pelajaran di sekolah dirasakan sangat diperlukan keberadaannya bagi siswa, karena pelajaran ini memiliki sifat multilingual, multidimensional, dan multikultur (Ahmad Susanto, 2013). Multilingual berarti bertujuan mengembangkan kemampuan mengapresiasikan diri dengan berbagai cara. Multidimensional berarti bahwa mengembangakan kompetensi kemampuan dasar siswa yang mencakup persepsi, pengetahuan, pemahaman, analisis, evaluasi, apresiasi, dan produktivitas dalam menyeimbangkan fungsi otak kanan dan kiri, dengan memadukan unsur logika, etika, dan estetika. Adapun multikultural berarti bertujuan menumbuh kembangkan kesadaran dan kemampuan berapresiasi terhadap keragaman budaya lokal dan global sebagai pembentuk sikap menghargai, demokrasi, beradab, dan hidup rukun dalam masyarakat dan budaya yang majemuk.

\section{Seni Cukil dan Pendidikan Seni}

Pendidikan seni budaya memiliki peranan dalam pembentukan pribadi peserta didik yang harmonis dengan memerhatikan kebutuhan perkembangan anak dalam mencapai multi kecerdasan yang terdiri atas kecerdasan intrapersonal, kecerdasan intrapersonal, visual, spasial, moral, emosional, musikal, logik, kinestetik, linguistik, matematis, dan 
kecerdasan naturalis. Bidang seni rupa, seni musik, seni tari, dan juga keterampilan ini memiliki kekhasan tersendiri sesuai dengan kaidah keilmuan masing - masing. Dalam pendidikan seni keterampilan, aktivitas berkesenian harus menempung kekhasan tersebut yang tertuang dalam pemberian pengalaman pengembangan konsepsi, apresiasi, dan kreasi. Semua ini diperoleh melalui upaya eksplorasi elemen, prinsip, proses, dan teknik berkarya dalam konteks budaya masyarakat yang beragam. Potensi yang dimiliki anak sejak lahir dapat dikembangkan secara optimal dengan pendidikan seni sebagai media untuk peningkatan kreativitas mereka. Pendidikan seni budaya menurut (Ahmad Susanto, 2013) diberikan disekolah dikarenakan keunikan, kebermaknaan, dan kebermanfaatan terhadap suatu kebutuhan perkembangan peserta didik, yang teretak pada pemberian pengalaman estetik dalam bentuk sebuah kegiatan berekspresi atau berkreasi dan berapresiasi pendekatan "belajar dengan seni", "belajar melalui seni", dan "belajar tentang seni". Peran ini tidak dapat diberikan oleh mata pelajaran lain. Fungsi dan tujuan pelajaran seni budaya adalah untuk mengembangkan sikap dan kemampuan siswa agar mampu berkreasi dan peka dalam hal seni ataupun kemampuan nya dalam berkarya atau menghasilkan suatu karya

Seni cukil di Indonesia sudah dikenal sejak masa perjungan. Poster - poster perjuangan serta selebaran propaganda banyak menggunakan media cukil sebagai pilihan 


\section{$e^{I-T a r b a w j ~ A d e n ~ W i j d a n ~ S Z ~ \& ~ J u n a n a h ~}$}

sarana utama. Seni cukil atau teknik cetak tinggi merupakan seni grafis yang sampai saat ini masih cukup populer di Indonesia mendominasi teknik - teknik lain nya. Sebagian seniman masih menyukai dan menggunakan seni cukil atau teknik cetak tinggi dikarenakan efek estetiknya mempunyai ciri khas yang tidak dapat di jangkau oleh teknologi canggih yang berkembang saat ini. Salah satu yang menonjol dari seni ini adalah pada kondisi ketidak tersediaan peralatan yang canggih teknik ini masih dapat diterapkan untuk memperbanyak gambar yang akan digunakan untuk keperluan komersial. Asia timur merupakan satu satunya dan yang mengawali teknik cukil kayu (woodcut) yang digunakan secara tradisional. Seni cukil kayu ini juga dapat disebut sengan istirlah xilografi (xylograohy).

Teknik cukil atau cetak tinggi menghasilkan tulisan atau gambar dengan proses cetak menggunakan permukaan lembar kayu, linoleum, hardboard atau karet vinyl yang dicukil atau dipahat yang digunakan sebagai plat atau acuan cetak. Pada bagian yang tidak di cetak atau bukan merupakan gambar di cukil atau di pahat, sebaliknya yang merupakan gambar dibiarkan sejajar dengan permukaan plat. Cat atau pewarna di bumbuhi dalam plat yang sejajar tersebut yang kemudian plat di taruh diatas media yang akan disablon. Plat tersebut di injak dan digosok kan bisa juga di bantu dengan sendok untuk menekan atau juga dengan alat press. Jika akan menggunakan berbagai warna maka harus menggunakan plat atau acuan 
cetak yang berbeda untuk setiap warna yang akan digunakan. Sehingga dari prinsip kerja sablon cukil adalah permukaan yang timbul (bagian positif) dan permukaan yang cekung adalah bagian negatif. Bagian negatif tidak menghasilkan warna atau tidak terkena warna, sebaliknya yang postitif atau tidak tercukil yang menghasilkan warna. Pada bagian yang tidak tercukil atau timbul diberi tinta dengan menggunakan roller yang kemudian diletakkan di media yang akan digunakan sebagai bidang cetak, hal ini bertolak belakang dengan dengan cetak intaglio dan etsa (etching) dimana bagain yang tergoreslah yang menampung tinta yang di cetak kan pada media yang diinginkan atau media yang dicetak. Teknik cukil atau cetak tinggi ini menggunakan peralatan yang sederhana dan tidak membutuhkan teknologi yang canggih, sehingga seniman dapat menuangkan ide dan gagasan dengan lebih ekspresif untuk menghasilkan karya seni grafis dengan teknik ini. Disamping itu juga beberapa nilai etestika yang tidak dapat di peroleh dan dihasilkan dengan teknologi canggih justru dapat di peroleh dengan teknik ini. Semua proses dilakukan secara manual walaupun tidak menutup kemungkinan jika sketsa gambar yang dihasilkan merupakan printout, inilah yang menjadi pembeda seni cukil dengan teknik cetak yang lain.

Dalam kegiatan pengabdian masyarakat ini dibagi menjadi tiga (3) tahap dalam pelaksanaannya meluputi: Pra Pelaksanaan Tahapan kegiatan dimulai dengan koordinasi dengan mitra pengabdian masyarakat yaitu Pemerintah 


\section{$\mathrm{e}^{\mathrm{I}-\text { Tarbawj Aden Wijdan SZ \& Junanah }}$}

Kalurahan Petir. Pertemuan dengan Kepala Desa ini menjelaskan maksud dan tujuan serta target yang ingin dicapai beserta tentang tahapan - tahapan kegiatan pengabdian yang akan dilaksanakan di Sanggar Lumbung Kawruh.

\section{Tahapan Proses Pengabdian}

Tim Pengabdi bertemu dengan Bapak Sarju, SIP selaku Lurah Kalurahan Petir Kapanewon Rongkop Gunugkidul. Tahap berikutnya tim pengabdi melakukan Focus Group Discussion (FGD) yang dilaksanakan di Sanggar Lumbung Kawruh. dihadiri oleh Bapak Sarju, SIP selaku Lurah Kalurahan Petir, Bapak Rusmiyanto selaku Kepala Dukuh Padukuhan Ngurak Urak dan ketua serta jajaran anggota Sanggar Lumbung Kawruh. Beberapa poin yang di hasilkan dalam FGD ini antara lain: Pertama, perlunya sumber daya manusia untuk regenerasi untuk mempertahankan keberadaan sablon cukil di Kalurahan Petir sehingga perlunya diadakan workshop dan pelatihan untuk hal tersebut serta pengenalan media sosial untuk promosi. Kedua, Pembuatan foto dan video hasil karya sablon cukil yang nantinya dapat digunakan sebagai bahan untuk promosi di media sosial.

Pelaksanaan Program Pelaksanaan kegiatan workshop dan pelatihan dilaksanakan selama dua hari dengan mengundang pemuda - pemudi dan anak - anak yang merupakan perwakilan dari 13 Padukuhan yang ada di Kalurahan Petir. 
1. Workshop dan Pelatihan Hari Pertama

Hari pertama workshop dan pelatihan diikuti oleh 27 peserta yang merupakan wakil dari beberapa padukuhan yang ada di Kalurahan Petir. Tahap pelaksanaan dan materi pada hari pertama ini adalah:

Pembukaan Pembukaan Workshop dihadiri oleh Bapak Sarju, SIP selaku Lurah Kalurahan Petir, Bapak Rusmiyanto selaku Kepala Dukuh Padukuhan Ngurak Urak, beberapa Kepala Dukuh, Pengabdi dan Assistant (Mahasiswa) serta Pengelola Sangar Lumbung Kawruh dan Peserta Workshop. Peserta cukup beragam dari mulai anak Sekolah Dasar (SD), Sekolah Lanjutan Tingkat Pertama (SLTP), Sekolah Lanjutan Tingkat Atas (SLTA) hingga Mahasiswa. Hal ini untuk membuktikan bahwa berkreasi menggambar dan mencukil di papan kayu MDF sebagai bahan film dapat dilakukan dari anak - anak Sekolah Dasar (SD) jika dilatih dan di arahkan dengan baik.

Pelatihan penggambaran dengan system mirror Workshop dimulai dengan bagaimana proses menggambar di papan yang akan digunakan sebagai film sablon dalam posisi mirror alias terbalik. Hal ini menjadi tantangan tersendiri bagi peserta yang belum pernah menggambar mirror. Peserta langsung melukis/ menggambar di papan MDF yang disedikan dengan pensil. Tidak ada ketentuan yang diberikan ke perserta dalam penggambaran tersebut, 


\section{$e^{\text {I-Tarbawj Aden Wijdan SZ \& Junanah }}$}

masing - masing mengambar sesuai dengan keinginannya. Selesai mengambar, peserta langsung melakukan proses cukil, dalam proses ini peserta harus memperhatikan mana yang akan timbul menjadi gambar saat disablon dan mana yang harus tidak tersablon.

2. Workshop dan Pelatihan Hari Kedua

Sebelum ditutup pada hari pertama beberapa peserta yang belum selesai mencukil bisa menyelesaikan di rumah sehingga pada pertemuan kedua sudah siap untuk di sablon kan ke dalam media kaos. Pada hari kedua peserta sedikit berkurang hanya dihadiri oleh 21 peserta. Fokus Workshop dan Pelatihan pada hari kedua ini meliputi a. Proses memberi tinta pada papan ( sebagai film ) Selanjutnya setelah selesai mencukil gambar di dalam papan, kemudian papan diberikan tinta sablon. Sebelum diberi tinta kaos yang akan di sablon disiapkan terlebih dahulu agar selesai pemberian tinta langsung bisa di proses sablon ke media kaos.

Sablon Kaos dengan Papan Salah satu proses yang unik dalam sablon cukil ini adalah dilakukan dengan sangat manual, dimana setelah kaos di lekatkan pada papan kemudian papan MDF yang telah selesai dicukil dikasih tinta kemudian papan tersebut dilekatkan pada kaos di papan, kemudian di injak - injak agar tinta sablon melekat di media kaos. Dalam proses ini peserta sangat menikmati 
khusus nya saat melakukan injakan ke papan yang di lekatkan di kaos. Setelah selesai kemudian kaos yang sudah selesai di kasih tinta di jemur hingga kering. Promosi hasil Kaos Sablon Cukil Dari hasil sablon cukil ini kemudian peserta diberikan pengetahuan tentang pemasaran di media sosial untuk dapat mengenalkan dan memasarkan kaos sablon cukil ini.

\section{Kesimpulan}

Melalui program pengabdian masyarakat Pengembangan Ekonomi Kreatif Sablon Cukil di sanggar lumbung kawruh ini dapat disimpulkan bahwa Pendidikan kewirausahaan berlangsung dengan baik dan memberikan dampak yang baik bagi masyarakat. Di antaranya, sablon cukil merupakan seni mengambar yang membutuhkan kejelian, ketelitian, kecermatan dan kepekaan sosial. Karya yang di hasilkan dari sablon cukil bukan sekedar desain yang enak untuk dipandang namun juga melukiskan kondisi masyarakat sekitar kita. Dengan teknik mengajar yang tepat siswa tingkat sekolah dasar dapat mengikuti proses pelatihan dan bisa menghasilkan karya yang mempunyai seni dengan nilai jual tinggi. Teknik dalam sablon cukil dapat dijadikan referensi untuk pengembangan kraeatifitas dunia pendidikan dalam pelajaran seni rupa. Hasil sablon cukil bukan hanya di pandang dari sudut hasilnya 


\section{$e^{I-T a r b a w j ~ A d e n ~ W i j d a n ~ S Z ~ \& ~ J u n a n a h ~}$}

namun perlu di hargai dari proses dan seni yang melekat di dalamnya. 
Pendidikan Kewirausahaan Melalui Pengembangan Ekonomi... el-Tarbawj

\section{Daftar Pustaka}

Arijanto, Agus, 2012. Etika Bisnis bagi Pelaku Bisnis. Jakarta: Penerbit Raja Grafindo Persada.

Barmin \& Eko Wijiono. 2007. Seni Budaya dan keterampilan 6. Solo : PT. Tiga Serangkai.

Fakhriyani, Diana Vidya. (2016). Pengembangan Kreativitas Anak Usia

Dini.

Jurnal Wacana Didaktika Jurnal Pemikiran Penelitian Pendidikan Dan Sains Vol. 4 No.2

Felix, John. (2012). Pengertian Seni Sebagai Pengantar Kuliah Sejarah Seni Rupa, Jurnal Humaniora Vol.3 No.2

Kasmir. 2012. Kewirausahaan. Jakarta: PT Raja Grafindo Persada

Mulyani, Endang. (2011). Model Pendidikan Kewirausahaan di

Pendidikan Dasar dan Menengah. Jurnal Ekonomi $\mathcal{E}$ Pendidikan. Vol. 8 No.1

Praswoto, Andi. (2017). Menyusun Rencana Pelaksanaan Pembelajaran (RPP) Tematik Terpadu. Jakarta: Kencana.

Rokhmat, Nur. (1997). Cetak Tinggi: Cukil Kayu Sebagai Corak dalam Seni Grafis. Jurnal Media Vol XX, No.1

Saiman, Leonardus. 2014. Kewirausahaan. Jakarta: Salemba Empat

Sanusi, H. \& Hidayah, A.K. (2015). Pengkajian Potensi Desa dengan Pendekatan Partisipatif Di Desa Mawai Indah Kecamatan Batu Ampar Kabupaten Kutai Timur. Jurnal Agrifor. Vol. 14 No. 2 


\section{$e^{I-T a r b a w j}$ Aden Wijdan sz \& Junanah}

Sastra, M.Oscar. (2007). Modul Pembelajaran Seni Grafis I. Bandung: FPSD UPI Bandung.

Suharyono, 2017. Sikap dan Perilaku Wirausahawan. Jurnal Ilmu dan Budaya, Vol. 40, No.56

Susanto, Ahmad. 2013. Teori Belajar dan Pembelajaran di Sekolah Dasar. Jakarta: Prenadamedia Group.

www.senirupa.id

www.wartahandayani.com 